\title{
PENGARUH MODERNITAS INDIVIDU DAN LINGKUNGAN SOSIAL TERHADAP GAYA HIDUP PADA SISWA SMK BISNIS DAN MANAJEMEN TERAKREDITASI ADI KOTA BANDUNG
}

\author{
Oleh : Entin Jumantini \\ jumantinie04@gmail.com
}

\begin{abstract}
Abstrak
Penelitian ini bertujuan untuk mengukur dan menganalisis pengaruh modernitas individu dan lingkungan sosial terhadap gaya hidup siswa. Penelitian ini menggunakan pendekatan kuantitatif dengan metode survey, sedangkan teknis analisis yang digunakan adalah analisis model persamaan structural. Pengumpulan data dilakukan dengan menggunakan instrument kuesioner. Populasi dalam penelitian ini adalah populasi sasaran yaitu siswa pada 12 SMK Bisnis dan Manajemen yang terakreditasi A di Kota Bandung. Penarikan sampel dilakukan dengan teknik proportionale random samplinguntuk menentukan jumlah siswa yang menjadi sampel. Hasil penelitian menunjukkan bahwa modernitas individu dan lingkungan social berpengaruh positif terhadap gaya hidup. Kesimpulannya bahwa tinggi rendahnya gaya hidup dipengaruhi oleh modernitas individu dan lingkungan sosial.
\end{abstract}

Kata Kunci : modernitas individu, lingkungan sosial, gaya hidup

\section{PENDAHULUAN}

Pengaruh globalisasi berimbas kepada pemenuhan kebutuhan gaya hidup remaja saat ini. Perilaku gaya hidup hedonisme yang tampak di kalangan remaja saat ini merupakan akibat dari adanya perubahan kehidupan masyarakat modern dan adanya perubahan pada proses perkembangan individu. Hal ini ditandai dengan keinginan untuk mandiri dan mencari konsep diri pada remaja.

Dilihat dari segi usia, siswa SMK masih tergolong pada kelompok usia remaja yakni antara 15-18 tahun.Sesuai dengan yang diungkapkan oleh Kunto (1999: 87) bahwa remaja adalah generasi yang paling mudah terpengaruh oleh era globalisasi atau era modern. Saat ini dampak modernisasi pada remaja sudah sangat mudah ditemukan dalam kehidupan sehari-hari. Tampak ada perbedaan nilai pada remaja generasi sebelumnya. Perbedaan tersebut nampak dari kecenderungan perilaku pada remaja jaman sekarang yang dihadapkan pada gaya hidup yang hedonis dan mengutamakan kesenangan semata sebagai tujuan hidup.

Loudon dan Bitta (1993: 149) berpendapat bahwa remaja adalah kelompok yang berorientasi konsumtif karena remaja suka mencoba hal-hal baru, tidak realistik dan cenderung boros.

Gaya hidup hedonisme yang terjadi pada remaja seringkali terjadi karena remaja berada dalam rentang usia dengan tugas perkembangan masa peralihan dan pencarian identitas. Lingkungan pergaulan remaja merupakan salah satu faktor penting dalam terbentuknya kecenderungan perilaku konsumtif yang merupakan bagian dari gaya hidup hedonis. Hal ini terjadi karena remaja ingin melepaskan diri dari pengaruh kedua orangtuanya. Oleh karena itu, seringkali remaja dijadikan sebagai target pemasaran beragam jenis produk dan jasa yang ditawarkan. Remaja dianggap sebagai pasar yang potensial bagi produsen karena pada umunya remaja mudah terbujuk rayuan iklan, ikut- ikutan teman, mengikuti mode dan seringkali 
mereka mementingkan gengsinya agar dianggap tidak ketinggalan jaman.

Engel, Blackwell dan Miniard (1995) mengatakan bahwa terbentuknya perilaku konsumtif pada remaja dipengaruhi oleh beberapa faktor. Salah satu faktor yang berpengaruh terhadap terbentuknya perilaku konsumtif adalah kelompok referensi. Kelompok referensi merupakan sekelompok orang yang sangat mempengaruhi perilaku individu. Seseorang akan melihat kelompok referensinya dalam menentukan produk yang dikonsumsinya. Pendapat tersebut kemudian diperkuat oleh Howkins, Coney dan Bert (1980) yang mengatakan bahwa kelompok referensi merupakan suatu kelompok yang memiliki nilai- nilai dan pandangan yang digunakan oleh suatu individu yang termasuk didalamnya sebagai suatu landasan untuk perilakunya. Sumartono (2002) kemudian mengatakan bahwa perilaku konsumen yang terbentuk dalam kelompok referensi remaja akan mempengaruhi perilaku membeli remaja yang menjadi bagian dari kelompok referensi tersebut.

Di kalangan remaja yang memiliki orang tua dengan kelas ekonomi yang menengah ke atas, terutama di kotakota besar, mall sudah menjadi rumah kedua. Mereka ingin menunjukkan bahwa mereka juga dapat mengikuti mode yang sudah beredar.

Perilaku siswa yang cenderung konsumtif dan kurang memperhatikan skala prioritas, selain dipengaruhi oleh perkembangan zaman, juga karena kondisi psikologis siswa yang masih dalam pencarian identitas diri. Siswa ingin diakui eksistensinya oleh lingkungan dengan berusaha menjadi bagian dari lingkungan itu. Bagi mereka membeli tidak lagi dilakukan karena produk tersebut memang dibutuhkan, namun membeli dilakukan karena alasan-alasan lain seperti mengikuti trend, ingin mencoba produk baru, dan ingin memperoleh pengakuan sosial.
Kebutuhan untuk diterima dan menjadi sama dengan orang lain yang sebaya menyebabkan siswa berusaha untuk mengikuti berbagai atribut yang sedang ngetrend. Sekalipun atribut-atribut tersebut tidak mendukung eksistensinya sebagai siswa.

Lingkungan sosial terdiri atas kelompok acuan, peran keluarga dan status sosial. Dengan demikian, lingkungan tempat dimana seseorang berinteraksipun turut serta mempengaruhi gaya hidup siswa. Gaya hidup hedonis itu sendiri sebenarnya merupakan wujud ekspresi dari perilaku eksperimental yang dimiliki oleh remaja untuk mencoba sesuatu hal yang baru.Remaja sangat antusias terhadap adanya hal yang baru. Gaya hidup hedonisme sangat menarik bagi mereka, dimana prilaku pada remaja hanya menginginkan kesenangan. Perilaku tersebut lama kelamaan mengakar dalam kehidupan masyarakat termasuk para remaja yang pada akhirnya menjadi seperti sebuah budaya.

Ungkapan tersebut didukung oleh fakta yang didapat melalui jajak pendapat yang dilakukan oleh Kasali (1998: 197) yang menemukan bahwa mall adalah tempat nongkrong yang paling popular untuk mengisi waktu luang remaja $(30,8 \%)$, sedangkan jajan merupakan prioritas pertama pengeluaran remaja $(49,4 \%)$, setelah itu membeli alat sekolah $(19,5 \%)$, jalanjalan atau hura-hura $(9,8 \%)$, membeli kaset (2,3\%), membeli aksesoris mobil $(0,6 \%)$, dan ada pula yang tidak menjawab sebanyak $(0,4 \%)$. Hasil jajak pendapat tersebut menunjukkan bahwa remaja saat ini lebih berorientasi pada gaya hidup hedonis.

Berdasarkan fenomena di atas, peneliti mencoba mencari jawaban faktor-faktor apa yang mempengaruhi gaya hidup dengan melakukan penelitian pada siswa SMK Bidang Keahlian Bisnis dan Manajemen di Kota Bandung. 


\section{METODOLOGI}

Penelitian ini menggunakan pendekatan kuantitatif karena data penelitian berupa angka-angka dan analisisnya menggunakan statistik. Penelitian ini bertujuan untuk mengetahui bagaimana pengaruh modernitas individu, lingkungan sosial terhadap gaya hidup siswa. Metode yang digunakan adalah metode survey (explanatory survey), yaitu menjelaskan hubungan kausal dan pengujian hipotesis. Singarimbun (2008:3) mengatakan bahwa penelitian survey adalah penelitian yang mengambil sampel dari satu populasi dan menggunakan kuesioner sebagai pengumpul data yang pokok. Tujuan utama dari penelitian survei adalah mengetahui gambaran umum karakteristik dari populasi.

Populasi dalam penelitian ini adalah siswa pada 12 SMK Bisnis Manajemen yang terakreditasi A di Kota Bandung. yang terdiri atas 3 SMK Bisnis dan Manajemen Negeri dan 9 SMK Bisnis dan Manajemen Swasta. Teknik pengambilan sampel

\section{PEMBAHASAN}

a. Pengaruh Modernitas Individu terhadap Gaya Hidup

Hasil pengujian hipotesis menunjukkan bahwa modernitas individu berpengaruh positif terhadap gaya hidup. Besarnya pengaruh modernitas individu terhadap gaya hidup adalah 0,659 pada tingkat kesalahan $5 \%$. Hal ini dapat diterima karena modernitas merupakan suatu usaha untuk hidup sesuai dengan zaman. Zaman akan terus berubah seiring dengan perubahan waktu yang ada, tetapi sebagai individu harus terus dapat menyesuaikan dengan perubahan yang amat cepat tersebut.

Modernitas meliputi semua perubahan yang dialami individu dalam masyarakat. Perubahan sosial merupakan bagian dari perubahan kebudayaan, perubahan dalam untuk menentukan unit analisis dengan teknik proportionate random sampling. Penentuan jumlah sampel siswa dilakukan melalui perhitungan dengan menggunakan rumus dari Taro Yamane. Berdasarkan rumus tersebut, apabila sampel error sebesar 5\%, maka besarnya sampel dalam penelitian ini adalah 386 siswa.

Pengujian hipotesis dalam penelitian ini menggunakan analisis model persamaan structural atau pada umumnya disebut dengan Struktural Equation Modelling (SEM). SEM merupakan suatu teknik statistic yang digunakan untuk menguji serangkaian hubungan antara beberapa variabel.

Pengujian hipotesis dalam penelitian ini menggunakan analisis model persamaan structural atau pada umumnya disebut dengan Struktural Equation Modelling (SEM). SEM merupakan suatu teknik statistic yang digunakan untuk menguji serangkaian hubungan antara beberapa variabel.

kebudayaan mencakup semua bagiannya yaitu : kesenian, ilmu pengetahuan, teknologi, filsafat, bahkan perubahan dalam bentuk serta aturan organisasi sosial. Modernisasi merupakan salah satu penyebab terjadinya perubahan sosial dan budaya Indonesia. Modernisasi digunakan untuk menunjuk pada berbagai tahapan perkembangan sosial yang didasarkan pada industrialisasi, pertumbuhan ilmu dan teknologi, negara bangsa modern, pasar dunia kapitalis, urbanisasi, dan berbagai unsur infrastruktur lainnya. Penyebab utama lain dalam perubahan sosial dan budaya di Indonesia yaitu globalisasi. Masyarakat telah mampu melakukan transaksi ekonomi dan informasi dalam waktu singkat melalui teknologi satelit dan komputer. Misalnya adalah para siswa yang 
pesan pakaian, sepatu, dan tas melalui online shop agar lebih praktis dalam mendapatkan sesuatu yang mereka inginkan. Masyarakat yang terpengaruh budaya global secara sadar atau tidak telah memiliki suatu pola perilaku baru yang khas. Pola perilaku tersebut merupakan sebuah proses pembentukan gaya hidup. Ini berarti bahwa perubahan sosial dan budaya di Indonesia yang disebabkan oleh globalisasi dan modernisasi salah satunyan tampak pada gaya hidup masyarakat.

Gaya hidup bagian dari kehidupan sosial sehari- hari yang telah menjadi trend yang semakin berubah ke arah suatu keniscayaan ketika didalamnya media massa juga turut berperan dan menjadi hal penting dalam membentuk pola budaya konsumtif. Sebelum terjadi budaya konsumtif, awalnya masyarakat hanya mengkonsumsi barang untuk kebutuhan produksi dan konsumsi yang cukup. Namun sekarang semuanya masyarakat sekarang lebih suka mengkonsumsi segala sesuatunya dengan berlebihan. Media massa telah memberi klaim rasa kepercayaan diri dan eksklusif kepada masyarakat. Maka diperoleh juga prestise, status, kelas, dan symbol sosial tertentu. Konsumerisme dalam kehidupan modern menjelma menjadi sesuatu yang harus segera dipenuhi dan dipuaskan kebutuhannya. Identitas diri ditunjukan dengan berbagai macam produk unggulan yang masyarakat gunakan, diperoleh melalui iklan media massa. Akhirnya masyarakatpun mengabaikan tentang nilai dan kegunaan dari berbagai macam barang yang dibeli, sehingga budaya konsumtif memang telah menjadi gaya hidup masyarakat.

Modernisasi yang dilakukan oleh siswa masa kini cenderung ke arah westernisasi, tapi yang ditiru sebatas pada mode, padahal yang diharapkan oleh modernisasi adalah rasionalitas dan cara berfikir yang tangkas.

Pemaparan di atas didukung oleh pendapat Barker (2005: 176177) dinamisme modernitas menyebar dari markasnya di Eropa menuju seluruh penjuru bumi. Lembaga modernitas yang lahir di Barat ini dinamis dan mengglobal karena, seperti yang ditulis Giddens: Dinamisme modernitas diturunkan dari pemisahan ruang dari waktu dan penggabungan ulang keduanya dalam bentuk-bentuk yang memungkinkan "pen-zona-an" ruang waktu; pencabutan (dismbedding) sistem-sistem sosial (fenomena yang erat terkait dengan faktor-faktor yang terlibat dengan pemisahan ruang- waktu); dan penataan ulang refleksif atas hubungan sosial yang dipandu terus oleh masukanmasukan pengetahuan yang mempengaruhi tindakan individu dan kelompok.

Berdasarkan pemaparan di atas, dapat diketahui bahwa tinggi rendahnya tingkat modernitas akan mempengaruhi gaya hidup, semakin tinggi tingkat modernitas seseorang, maka akan semakin rasional gaya hidupnya. Artinya, gaya hidup yang dijalani sesuai dengan anggaran yang dimiliki sehingga tidak terjadi defisit.

b. Pengaruh Lingkungan Sosial terhadap Gaya Hidup

Hasil analisis data penelitian dan uji hipotesis menunjukkan bahwa lingkungan sosial berpengaruh positif dan signifikan terhadap gaya hidup siswa SMK di Kota Bandung. Hal ini dapat dilihat dari hasil uji signifikansi yang lebih kecil dari 0,05. Artinya semakin atas lingkungan sosial seseorang maka akan meningkatkan gaya hidupnya. Hal ini sejalan dengan hakikat manusia sebagai makhluk sosial, dimana segala sesuatu yang terjadi di hidupnya tidak akan pernah terlepas dari orang lain. Hal tersebut semakin memperkuat adanya pengaruh lingkungan dan 
orang-orang sekitar terhadap gaya hidup seseorang.

Perubahan gaya hidup manusia akibat lingkungan dan perilaku orang lain seperti yang banyak terjadi sekarang ini menjadikan intisari kebutuhan pokok manusia sudah bergeser. Kebutuhan pokok seseorang tidak hanya sandang pangan papan lagi, tetapi juga ditambah "gengsi".

Hasil penelitian ini juga didukung oleh penelitian yang dilakukan oleh Reynold menyatakan remaja usia $16 \mathrm{~s} / \mathrm{d} 18$ tahun membelanjakan uangnya lebih banyak untuk keperluan menunjang penampilan diri.

$\begin{array}{rrr}\text { Remaja } & \text { ingin } & \text { dianggap } \\ \text { keberadaannya } & \text { dan } & \text { diakui }\end{array}$ eksistensinya oleh lingkungan dengan berusaha menjadi lingkungan tersebut. Kebutuhan untuk diterima dan menjadi sama dengan orang lain yang sebaya itu menyebabkan remaja untuk mengikuti berbagai atribut yang sedang popular. Salah satu caranya adalah dengan berperilaku konsumtif, seperti: memakai barang-barang yang baru dan bermerk, memakai kendaraan ke sekolah, pergi ke tempat-tempat mewah untuk bersenang-senang ( diskotik, restoran, kafe dan tempattempat lainnya) di berbagai penjuru kota.

Dengan adanya semua fasilitas-fasilitas dan tempat perbelanjaan yang ada tersebut, memudahkan akses bagi masyarakat terutama remaja untuk berperilaku konsumtif. Karena untuk dianggap keberadaanya oleh lingkungan, ia harus menjadi lingkungan tersebut dengan cara mengkonsumsi dan menikmati semua fasilitas yang telah disediakan.

Hasil penelitian ini didukung juga oleh pendapat Amstrong (dalam Nugraheni,2003) yang menyatakan bahwa faktor-faktor yang mempengaruhi gaya hidup ada dua faktor yaitu faktor yang berasal dari dalam diri individu (internal) dan faktor yang berasal dari luar (eksternal). Faktor internal yaitu sikap, pengalaman dan pengamatan, kepribadian, konsep diri, motif, dan persepsi. Adapun faktor eksternal dijelaskan oleh Nugraheni (2003) sebagai berikut:

1). Kelompok referensi Kelompok referensi adalah kelompok yang memberikan pengaruh langsung atau tidak langsung terhadap sikap dan perilaku seseorang. Kelompok yang memberikan pengaruh langsung adalah kelompok dimana individu tersebut menjadi anggotanya dan saling berinteraksi. Sedangkan kelompok yang member pengaruh tidak langsung adalah kelompok dimana individu tidak menjadi anggota dalam kelompok tersebut. Pengaruh-pengaruh tersebut akan menghadapkan individu pada perilaku dan gaya hidup tertentu.

2). Keluarga

Keluarga memegang peranan

terbesar dan terlama dalam pembentukan sikap dan perilaku individu. Hal ini karena pola asuh orang tua akan membentuk kebiasaan anak secara tidak langsung mempengaruhi pola hidupnya.

3). Kelas Sosial

Kelas social adalah sebuah kelompok yang relative homogeny dan bertahan lama dalam sebuah masyarakat, yang tersusun dalam sebuah urutan jenjang, dan para anggota dalam setiap jenjang itu memiliki nilai, minat, dan tingkah laku yang sama. Ada dua unsure pokok dala sistem sosial pembagian kelas dalam masyarakat, yaitu kedudukan (status) dan peranan. Kedudukan social artinya tempat seseorang dalam lingkungan pergaulan, prestise hak-haknya serta kewajibannya. Kedudukan social dapat dicapai oleh seseorang dalam usaha yang sengaja maupun diperoleh karena kelahiran. Peranan merupakan aspek yang dinamis dari kedudukan. Apabila individu melaksanakan hak dan kewajibannya 
sesuai dengan kedudukannya, maka ia menjalankan suatu peran.

4). Kebudayaan

Kebudayaan yang meliputi pengetahuan, kepercayaan, kesenian, moral, hokum, adat istiadat, dan kebiasaan yang diperoleh individu sebagai anggota masyarakat. Kebudayaan terdiri dari segala sesuatu yang dipelajari dari pola-pola perilaku yang normatif, meliputi ciri-ciri pola pikir, merasakan, dan bertindak.

Berdasarkan pemaparan di atas dapat dilihat bahwa lingkungan sosial mempengaruhi gaya hidup secara positif. Hal ini berarti tinggi rendahnya pengaruh keluarga, lingkungan tempat tinggal, dan keinginan untuk diakui (eksistensi) dalam kelompok akan mempengaruhi gaya hidup siswa.

c. Pengaruh Modernitas Individu dan Lingkungan Sosial terhadap Gaya Hidup

Temuan penelitian menunjukkan tinggi rendahnya gaya hidup secara positif dipengaruhi oleh tinggi rendahnya modernitas individu dan lingkungan sosial, hal ini dapat dinilai dari nilai koefisien jalur $(\mathrm{SRW})>0$. Besarnya pengaruh lingkungan sosial dan modernitas terhadap gaya hidup masing-masing sebesar 0,296 dan 0,659. Sebesar. $86 \%$ tinggi rendahnya variasi yang terjadi pada gaya hidup dapat dijelaskan secara bersama-sama oleh modernitas individu dan lingkungan sosial. Sisanya sebesar $14 \%$ merupakan pengaruh variabel lain yang tidak dijelaskan dalam model.

Jika dilihat masing-masing kontribusi variabel modernitas individudan lingkungan sosial, dalam mempengaruhi variabel gaya hidup maka untuk variabel modernitas individu dapat dilihat bahwa indikator rasa percaya tanpa prasangka buruk memberikan kontribusi tertinggi yaitu sebesar 0,789 sedangkan indikator kemampuan memanfaatkan media massa memberikan kontribusi terendah yaitu 0,665 , sedangkan untuk variabel lingkungan sosial dapat dilihat indikator eksistensi dalam kelompok memberikan kontribusi tertinggi yaitu 0,829 sedangkan indikator lingkungan tempat tinggal memberikan kontribusi terendah yaitu sebesar 0,742

Tabel 3.1

Pengaruh Langsung $X_{1}, X_{2}$ terhadap $Y$

\begin{tabular}{|l|l|l|l|}
\hline \multirow{2}{*}{} & \multicolumn{3}{|l|}{ Pengaruh Langsung } \\
\cline { 2 - 4 } & $\mathrm{X}_{1}$ & $\mathrm{X}_{2}$ & \\
\hline $\mathrm{Y}$ & 0,296 & 0,659 & \\
\hline
\end{tabular}

\section{SIMPULAN}

1. Modernitas individu yang ditunjukkan oleh indikator keterbukaan terhadap pengalaman baru dan perubahan, sanggup berpendapat terhadap suatu persoalan, perencanaan dan orientasi, efikasi diri, sanggup meyakini kemampuan diri, partisipasi pendidikan, berani mengambil resiko, rasa percaya, optimis, dan kemampuan memanfaatkan media berpengaruh langsung terhadap gaya hidup. Hal ini menunjukkan bahwa modernitas individu dapat dijadikan sebagai predictor 
tinggi rendahnya gaya hidup. Maknanya semakin modern seseorang gaya hidupnya akan semakin rasional, karena salah satu ciri manusia modern adalah mempunyai perencanaan dan orientasi sehingga cenderung didasarkan pada pola pikir rasional atau logis.

2. Lingkungan Sosialberpengaruh positif terhadap gaya hidup. Hal ini menunjukkan bahwa lingkungan keluarga, lingkungan tempat tinggal dan eksistensi dalam kelompok memberikan kontribusi yang berarti pada gaya hidup siswa. Indikator eksistensi dalam kelompok memberikan kontribusi yang paling tinggi. Maknanya adalah semakin dapat mengontrol keinginan untuk diakui dalam kelompok maka gaya hidup nya akan rasional.

3. Modernitas individu, lingkungan sosial secara bersama-sama berpengaruh positif terhadap gaya hidup. Hal ini menunjukkan bahwa semakin tinggi tingkat rasionalitas pola pikir dan pola perilaku serta semakin tinggi tingkat kontrol diri dalam lingkungan sosial, maka semakin rasional pula gaya hidup siswa.

\section{Daftar Pustaka}

Anton, Barker. 2004. Alternatif Pengembangan Masyarakat Di Era Globalisasi. Jakarta: Kanisius

Engel, James F, Blackweel, Roger, Miniard, Paul W. 1994. Perilaku Konsumsi. Jakarta: Binarupa Aksara

Fatchur, Rohman. 2009. Peran Nilai Hedonik Konsumsi dan Reaksi Impulsif sebagai Mediasi Pengaruh Faktor Situasional terhadap Keputusan Pembelian Impulsif di Butik Kota Malang. Jurnal Aplikasi Manajemen. Vol.7 No.2

Howkins, Coney\&Bert. 1980. Consumer Behavior (Implications for Marketing Strategy). Texas: Business Publication.Inc

Kasali, Rhenald. 1998. Membidik Pasar Indonesia; Segmentasi, Targetting, dan Positioning. Jakarta: PT Gramedia Pusaka Utama

Kunto, Yohanes S \& Peter Remy P. 2006. Segmentasi gaya hidup pada mahasiswa program studi pemasaran Universitas Kristen Petra.Vol 1 No.1 april 2006, halaman 13-21.

Loudon, David L.;Bitta, Albert.J.Della. 1993. Consumer Behavior: Concepts and Application. Singapore: Mc Graw-Hill Book Company

Nugraheni,P.N.A.2003. Perbedaan Kecenderungan gaya Hidup Hedonis Pada Remaja Ditinjau dari Lokasi Tempat Tinggal. Skripsi (tidak diterbitkan).

Sumartono. 2002. Terperangkap Dalam Iklan (Meneropong Imbas Pesan Iklan Televisi). Bandung: Alfabeta. 